\title{
PENINGKATAN DAYA SAING PRODUK REMPEYEK KELOMPOK UPPKS LESTARI DI KELURAHAN SEI SIKAMBING C KOTA MEDAN
}

\author{
Tengku Teviana $^{1^{*}}$, Randeska Manullang ${ }^{1}$, Mica Siar Meiraza ${ }^{1}$ \\ ${ }^{1}$ Fakultas Ekonomi, Universitas Negeri Medan, Medan \\ *Penulis Korespodensi: teviana_tengku@yahoo.com
}

\begin{abstract}
Abstrak
Tujuan kegiatan Iptek bagi Masyarakat (IbM) ini adalah membantu mitra (Kelompok UPPKS Lestari) dalam menyelesaikan masalah-masalah utama yang dihadapi khususnya masalah yang berkaitan dengan perbaikan kualitas produk dan pemasarannya. Target khusus dalam kegiatan IbM ini akan dihasilkannya: 1) Peralatan produksi (alat pengering minyak), 2) Kelengkapan dan kelayakan administrasi kredit 3) desain kemasan, 4) Label Halal dari Majelis Ulama Indonesia (MUI) dan 5) Produk terdaftar di Badan Pengawas Obat dan Makanan (BPOM), 6) pangsa pasar baru. Metode pendekatan yang digunakan untuk mencapai tujuan kegitan IbM adalah pendekatan kelompok UPPKS dan metode pelaksanaannya meliputi: pendidikan, penyuluhan, pelatihan produksi, pelatihan manajemen usaha, dan pendampingan. Rencana kegiatan IbM yang akan dilakukan antara lain memberikan pendidikan dan pelatihan serta pendampingan dengan fase kegiatan sebagai berikut: 1) Pemberian alat produksi (alat pengering minyak), 2) pendidikan dan pelatihan Manajemen Usaha (Pengelolaan usaha, pengembangan pangsa pasar dan Pembukuan untuk usaha kecil, kelengkapan dan kelayakan adm kredit), 3) Pelatihan pembuatan desain kemasan (plastik kemasan, stiker dan alat pres) 4) Pengurusan Label halal dari MUI, 5) Mendaftarkan produk ke BPOM, serta 6) pendidikan dan pelatihan bidang pemasaran.
\end{abstract}

Kata Kunci: Alat Pengering Minyak, UPPKS, Rempeyek.

\begin{abstract}
The purpose of science and technology activities for the Society (IbM) is to help partners (Group UPPKS Lestari) in solving the main problems faced, especially issues related to improving product quality and marketing. Specific targets in this IbM activity will be produced: 1) Production equipment (oil dryers), 2) Completeness and feasibility of credit administration 3) packaging design, 4) Halal label from MUI and 5) Product registered in BPOM, 6) market share new. The approach method used to achieve IbM's activity objectives is the UPPKS group approach and its implementation methods include: education, counseling, production training, business management training, and mentoring. IbM's planned activities include providing education and training as well as mentoring with the activity phase as (2) education and training of business management (business management, development of market share and bookkeeping for small business, completeness and creditworthiness of admittance), 3) training of packaging design (packaging pelastics, stickers and press tools) 4) Handling Halal Label from MUI, 5) Registering product to BPOM and 6) education and training in product marketing.
\end{abstract}

Keywords: Oil Dryers, UPPKS, Rempeyek.

\section{PENDAHULUAN}

Dari hasil pendataan keluarga yang dilakukan oleh BkkbN, diketahui bahwa $56 \%$ dari 39,4 juta keluarga Indonesia masih berada dalam tahap tertinggal yang termasuk dalam kategori keluarga pra sejahtera dan keluarga sejahtera 1. Dari jumlah tersebut 11,5 juta keluarga tinggal di desa tidak tertinggal. Data ini menunjukkan bahwa sebahagian masyarakat kita masih hidup dalam kemiskinan dan belum dapat ikut serta menikamati hasil-hasil pembangunan. Oleh karena itu sudah menjadi kesepakatan dan tekad bersama seluruh elemen bangsa dapat berperan dalam mengentaskan kemiskinan bagi masyarakat Indonesia. fenomena diatas menandakan UMKM memiliki peran sangat vital dalam perekonomian negara, di saat krisis moneter 1998 UMKM menyumbang Rp552.945,40 miliar dari total GDP (Gross Domestic Produc).

Terbentuknya Kelompok UPPKS Lestari dikarenakan sekelompok masyarakat khususnya ibuibu rumah tangga berkeinginan untuk melakukan usaha produktif dengan harapan dapat membentu mengatasi masalah keuangan keluarga yang mereka hadapi. Mahalnya biaya pendidikan, kesehatan dan 
kebutuhan pokok membuat mitra harus bekerja keras untuk dapat tetap eksis dalam menghadapi kondisi ekonomi yang serba tidak menentu. Dampak dari naiknya harga bahan bakar minyak (BBM) yang diikuti oleh naiknya harga kebutuhan pokok terutama harga kebutuhan pokok menambah persoalan ekonomi keluarga semakin sulit. Mengatasi masalah tersebut mitra secara berkelompok dibina oleh pemerintah kecamatan mencoba memulai usaha pembuatan produk kuliner (rempeyek ikan dan kacang), dimasa perintisan; usaha yang mitra lakukan belum mendatangkan keuntungan seperti yang diharapkan, hal ini dikarenakan keterbatasan pengalaman dan pengetahuan mitra dalam berwirausaha dan ketidak mampuan mitra dalam menyelesaikan permasalahan yang dihadapinya dalam aspek produksi maupun aspek manajemen usaha.

Setelah beberapa waktu berjalan; dengan semangat kemandirian ternyata usaha yang mitra lakukan membuahkan hasil, ini dibuktikan dengan kemampuan mitra memperoleh penghasilan dari usaha yang dilakukannya; (walaupun sebenarnya belum memadai) secara langsung sangat membantu ekonomi keluarga dan mitra sedikit lega karena untuk keperluan sehari-hari sudah dapat diandalkan dari usaha yang mitra lakukan. Namun demikian, terkadang usaha yang mitra lakukan mengalami pasang surut.

Anggota kelompok UPPKS Lestari sampai sekarang ini sudah mencapai kurang lebih 20 orang dan diharapkan akan terus bertambah seiring berjalannya waktu. Oleh karena itu, tak mengherankan bila kelompok UPPKS Lestari ini menjadi salah satu wadah khususnya bagi masyarakat di kelurahan sei sikambing C jl Jawa No 72 C Kota Medan yang ingin melakukan aktifitas usaha dalam membantu memenuhi ekonomi keluarganya.

Permasalahan yang dihadapi mitra sekarang ini adalah masalah peningkatan kualitas produk dan pemasaran, termasuk juga masalah pengelolaan dan manajemen usaha. Masalah - masalah tersebut membuat usaha mitra sulit untuk berkembang. Namaun demikian semangat dan kreativitas merupakan modal utama bagi kelompok UPPKS Lestari tersebut.

Hasil survey pertama (12- Pebruari - 2015) di Kelurahan Sei Sikambing C jl Jawa No 72 C Kota Medan merupakan kelurahan yang terletak di kota medan, berjarak $20 \mathrm{~km}$ dari Unimed. Kelurahan tersebut merupakan lokasi dimana mitra melakukan aktifitas usahanya, dimana sekelompok masyarakat khususnya ibu-ibu rumah tangga yang tergabung dalam Kelompok UPPKS Lestari yang jumlah anggotanya sebanyak 20 orang menjalankan aktifitas usaha pembuatan produk kuliner (rempeyek ikan dan kacang).

Hasil survey kedua (12- Maret - 2015) di Kelurahan Sei Sikambing C jl Jawa No 72 C Kota Medan, terdapat Kelompok UPPKS Lestari yang diketuai oleh Ibu Yusmini dan Ibu Hafsah, berkeinginan mengembangkan usahanya, namun karena keterbatasan pengetahuan dan pengalaman dalam berwirausaha khususnya dalam hal perbaikan kualitas produk dan pemasarannya, hasil dari usaha ini belum memadai (stagnan); kelompok UPPKS Lestari belum pernah mendapat pengarahan ataupun penyuluhan tentang pengelolaan dan manajemen usaha dari pihak pemerintah dan pihak manapun. Untuk memperoleh permodalan; Kelompok UPPKS Lestari belum pernah mengajukan permohonan kredit ke lembaga perbankan, hal ini dikarenakan keterbatasan wawasan, pengetahuan dan pengalaman yang mitra miliki sehingga persyaratan administrasi untuk pengajuan kredit perbankan sulit untuk mitra lengkapi.

Perguruan Tinggi yang merupakan sentral ilmu pegetahuan, yang menjalankan perannya sebagai pelayan mahasiswa dan masyarakat melalui program IbM ini, berkeinginan membantu mitra (Kelompok UPPKS Lestari) menjadi lebih mandiri dan berkembang dari sebelumnya.

Berdasarkan kondisi mitra, kelompok UPPKS Lestari ini ingin usahanya berkembang; dengan tetap fokus pada usaha yang dilakukannya, dan berkeinginan mendapatkan pelatihan dan pendampingan dalam perbaikan kualitas produk dan pemasaran untuk produk yang dihasilkannya.

Kelompok UPPKS Lestari yang diketuai oleh Ibu Yusmini dan Ibu Hafsah, sebagaimana keterangan di atas bergerak di bidang usaha pembuatan produk kuliner (rempeyek ikan dan kacang). Kapasitas yang di hasilkan dari usaha tersebut adalah sebagai berikut :

\section{Produksi}

- Bahan Baku: terigu, ikan teri, udang kecepe dan kacang tanah

- Kuantitas Produksi: Secara keseluruhan UPPKS Lestari perharinya memproduksi kurang lebih: $200 \mathrm{~kg}$ rempeyek (ikan dan kacang) dengan harga jual 55.000/kg nya (masing-masing anggota maksimal produksi /hari $10 \mathrm{~kg}$ )

- Kualitas produksi: belum maksimal (rasa enak tetapi hasil gorengan warnanya tidak seragam)

- Kemasan: Kemasan dilakukan dengan cara sederhana menggunakan plastik biasa dan merekatkannya menggunakan lilin; hal ini membuat tampilan keripik menjadi kurang menarik; keripik dikemas dengan berbagai ukuran dengan harga bervariasi; mulai harga Rp.6000,/ons, Rp. 15000/250gr, Rp.30.000/500gr dan Rp. 60.000/kg. Mitra sangat berkeinginan untuk belajar bagaimana membuat kemasan yang menarik sehingga mitra berharap produknya dapat dikembangkan pangsa pasarnya dengan harapan keripiknya layak untuk dijual ketoko-toko bakery, supermarket dan lain-lain dengan harga yang relatif lebih mahal. 


\section{Promosi}

Promosi hanya sebatas dari mulut ke mulut, dalam hal ini mitra sangat berkeinginan untuk mendapatkan pelatihan atau pengetahuan dalam hal berpromosi.

\section{Pemasaran;}

Pemasaran dilakukan dengan cara:

- Menititipkan produknya di rumah- rumah makan/ restoran dan toko-toko yang ada disekitar mitra bahkan beberapa wilayah yang mampu mitra jangkau dengan cara bongkar pasang, maksudnya penjual hanya membayar sejumlah yang laku terjual dan barang sisa akan dikembalikan sembari menggantinya dengan barang yang baru; sampai sekarang ini pelanggan yang ada sudah mencapai 20 rumah makan dan 8 toko dan diperkirakan masih bisa ditingkatkan lagi jumlahnya.

- Dipasarkan oleh beberapa orang yang ada dilingkungan mitra dengan cara menjualnya secara langsung kepada konsumen rumah tangga (perumahan-perumahan dan perkantoran yang ada disekitar wilayah mitra).

\section{Pembukuan}

Dalam hal ini mitra hampir dipastikan tidak melakukaannya. walaupun secara teknis usaha yang mitra lakukan layak untuk mendapatkan kredit, tetapi karena tidak adanya pembukuan membuat mitra sulit mendapatkan kredit perbankan.

\section{Pengelolaan dan Manajemen usaha}

Meskipun menganut manajemen sederhana, sistem pembagian kerja sudah terorganisir dengan baik, artinya masing-masing anggota kelompok sudah memiliki tugas / pekerjaan masing-masing (bagian produksi, kemasan dan pemasaran) sehingga tidak terjadi suasana kerja yang semraut dan hanya saja masih perlu untuk dibenahi. Dan bila dilihat dari kemampuan produksi dan menghasilkan laba serta peluang yang ada dapat disimpulkan bahwa usaha yang dilakukan mitra cukup pontensial untuk berkembang.

Namun demikian usaha yang mitra lakukan masih belum memiliki SIUP, NPWP, Pembukuan, dalam kemasan produknya pun selain tidak menarik, kemasan juga belum berlabel halal dari MUI, dan juga belum terdaptar di BPOM, karena beberapa hal diatas sangat penting untuk dimiliki atau dilakukan agar produk mitra bisa memenuhi standart kualitas sehingga memenuhi persyaratan untuk dipasarkan di swalayan maupun suprmarket.

\section{a. Persoalan yang dihadapi Mitra}

Hasil pengamatan langsung (12 Maret 2015), kepada mitra yang tergabung dalam kelompok UPPKS Lestari sudah ditekuni sejak tahun 2012 dari tahun ke tahun terus mengalami perkembangan. Dalam aspek produksi mitra tidak mengalami kendala karena mitra sudah mampu mandiri untuk melakukannya; hanya saja kualitas produk masih kurang; hal ini disebabkan kepemilikan peralatan produksi yang kurang memadai; dari hasil pengamatan langsung yang dilakukan oleh tim pengusul dapat diidentifikasi beberapa permasalahan yang dihadapi mitra dan perlu untuk dicari solusinya. Masalah-masalah tersebut teridentifikasi sebagai berikut:

1. Pemodalan

2. Peralatan produksi kurang memadai

3. Kemasan kurang menarik

4. Tidak ada label halal dari MUI dalam kemasan produknya

5. Produk tidak terdaftar di BPOM.

6. Merek dagang belum ada (kemasan berupa plastik putih polos)

7. Pengembangan pangsa pasar

b. Penentuan Perioritas Permasalahan Mitra

Berdasarkan hasil diskusi bersama mitra (pada tanggal 12 maret 2015) disepakati perioritas permasalahan yang akan di selesaikan atau dicari solusinya baik dari aspek produksi maupun manajemen usaha adalah sebagai berikut:

1. Masalah peralatan produksi yang belum memadai

2. Masalah desain kemasan

3. Pengurusan label halal dai MUI

4. Mendaftarkan produk ke BPOM

5. Masalah Perluasan pangsa pasar

Masalah-masalah tersebut diatas sangat perlu untuk dicarikan solusinya, mengingat besarnya harapan dan keinginan mitra dalam mengembangkan usahanya sehingga pada akhirnya usaha tersebut dapat diandalkan sebagai sumber endapatan tambahan bagi keluarga dan nantinya layak untuk mendpatkan bantuan permodalan perbankan.

\section{c. Justifikasi Pengusul Bersama Mitra Dalam} Menentukan Masalah Perioritas

Berdasarkan hasil diskusi bersama mitra (tanggal 12 maret 2015) Justifikasi ditentukan terhadap masalah perioritas yang akan diselesaikan; adalah masalah prioritas yang menghambat perkembangan usaha mitra; meliputi masalah perbaikan kualitas produk dan pemasarannya, secara operasional dapat dijelaskan sebagai berikut:

1. Solusi untuk masalah peralatan produksi yang belum memadai mitra telah di beri peralatan produksi yang akan menunjang pernbaikan kualitas produknya meliputi kuali baja dengan kapasitas 20 liter minyak dan alat atau mesin pengering minyak dengan kapasitas $10 \mathrm{~kg}$, peralatan ini nantinya akan membuat kualitas produk menjadi lebih baik dan produk tidak mudah menjadi tengik (rusak).

2. Solusi untuk masalah desain kemasan mitra telah diberi pelatihan dan pendampingan pembuatan desain kemesan sehingga produk lebih menarik perhatian konsumen dan layak untuk dipasarkan di supermarket, dimana selama ini produk mitra hanya dikemas dengan pelastik biasa dan direkatkan menggunakan lilin. 
3. Mitra telah diberi pendampingan dalam pengurusan label halal dari MUI, hal ini penting sekali untuk dimiliki agar produk mitra layak atau memenuhi persyaratan untuk dipasarkan di supermarket.

4. Mitra telah diberi pendampingan untuk mendaftarkan produknya ke BPOM, hal ini juga penting sekali untuk dimiliki agar produk mitra layak atau memenuhi persyaratan untuk dipasarkan di supermarket.

5. Solusi untuk masalah perluasan pangsa pasar mitra telah diberi penyuluhan pemasaran dan perluasan pangsa pasar, dengan fokus kegiatan pada inovasi dan diversifikasi produk serta bauran pemasaran.

\section{TARGET DAN LUARAN}

Target yang hendak dicapai dalam kegiatan IbM ini adalah perbaikan kualitas produk dan pemasarannya, dengan Luaran sebagai berikut:

a) Peralatan penunjang perbaikan kualitas produk (alat pengering minyak)

b) Desain kemasan

c) Pangsa pasar baru

\section{Spesifikasi Luaran}

1) Spesifikasi Pralatan produksi Kapasitas : 5 Kg

Dimensi ( p x 1 x t) : 60x45x53cm

Bahan : - Frame : Pipa Besi Kotak

- Silinder : Stainless Steel

- Keranjang Bahan : Vorporasi SS

Ukuran Keranjang Bahan : O 32, $\mathrm{t}=24 \mathrm{~cm}$

Daya : 250 Watt

RPM : 900-1200 rpm

2) Spesifikasi Desain Kemasan

- Berlabel halal

- Berlabel BPOM

- Ada ijin produksi/IRT

- Ada tanggal kedaluarsa

- Bahan plastik
- Desain kemasan menggunakan stiker

3) Spesifikasi Pangsa pasar baru

- Super market

- Swalayan

- Perkantoran

\section{METODE PELAKSANAAN}

Berdasarkan permasalahan yang telah di kemukakan, maka dalam kegiatan $\mathrm{I}_{\mathrm{b}} \mathrm{M}$ ini metode pelaksanaan yang ditawarkan untuk solusi dari permasalahan mitra; adalah metode pendidikan, pelatihan dan pendampingan.

\section{HASIL DAN PEMBAHASAN}

Hasil yang dicapai dalam pelaksanaan kegiatan pengabdian masyarakat ini adalah:

\section{a. Aspek Produksi}

\section{- Sebelum Kegiatan}

Alat produksi belum memadai, sebelum dapat dikemas dan dipasarkan, mitra membutuhkan waktu 2 (dua) hari untuk meniriskan minyak goreng yang masih melekat pada produknya (rempeyek, stik keju, dll), dengan cara memasukkan produknya kedalam wadah stoples plastik berukuran besar (isi $10 \mathrm{~kg}$ ) yang didalamnya dilapisi koran untuk menyerap minyak goreng, selain tidak efisien kualitas produk juga tidak bertahan lama (produk mudah tengik atau melempem).

\section{- Setelah Kegiatan}

Mitra telah diberi alat produksi berupa mesin pengering minyak, dengan alat ini mitra hanya membutuhkan waktu kurang lebih 5 (lima) menit untuk meniriskan minyak yang melekat pada produk rempeyek dan stik keju untuk selanjutnya dapat dikemas dan dipasarkan, selain efisien, dengan alat ini kualitas produk mitra dapat terjaga dan produk tidak mudah tengik. 
Prosedur Kerja

Prosedur Kerja Untuk Mendukung Realisasi Metode Yang Ditawarkan

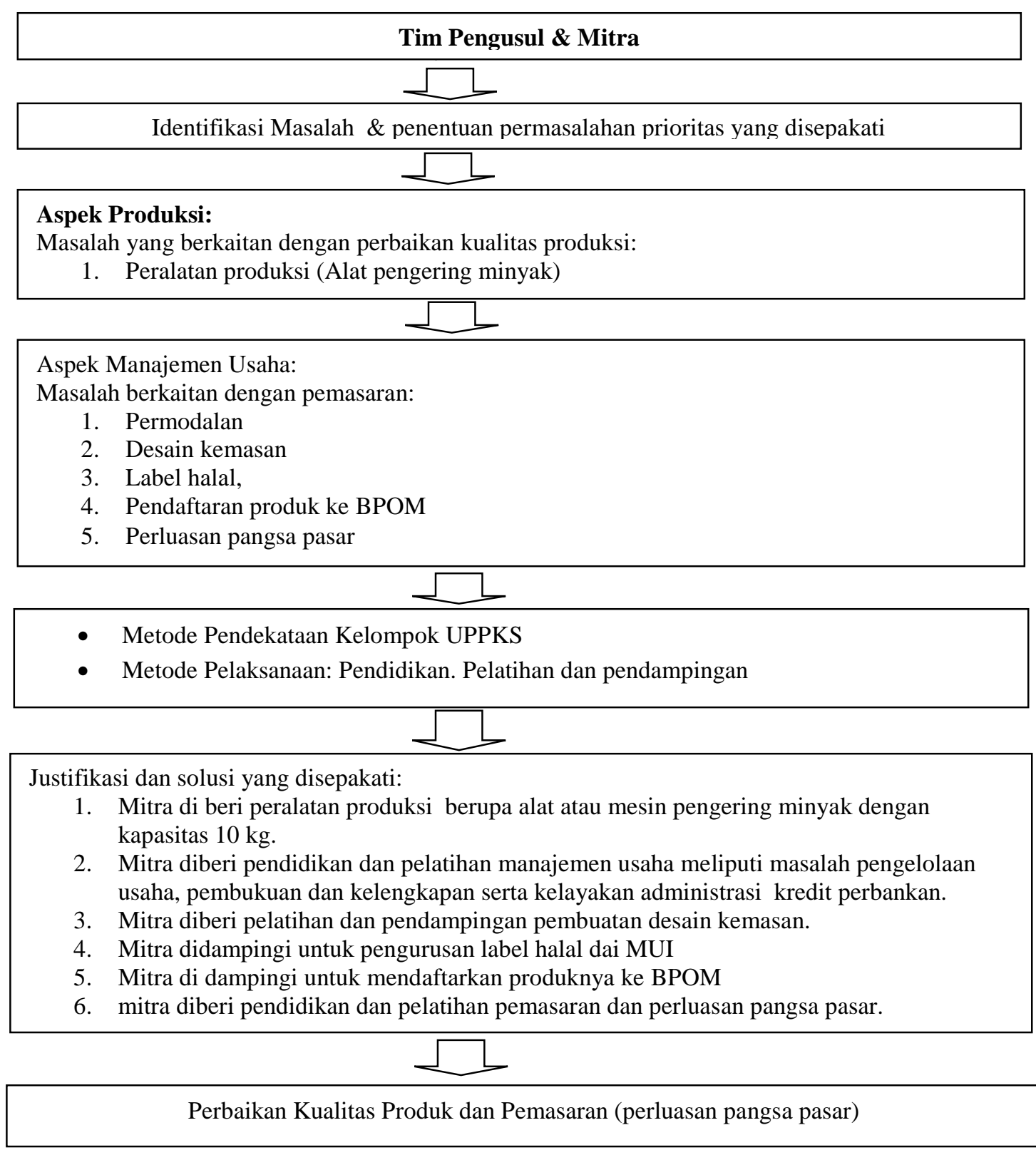

\section{Gambar: Prosedur Kerja}

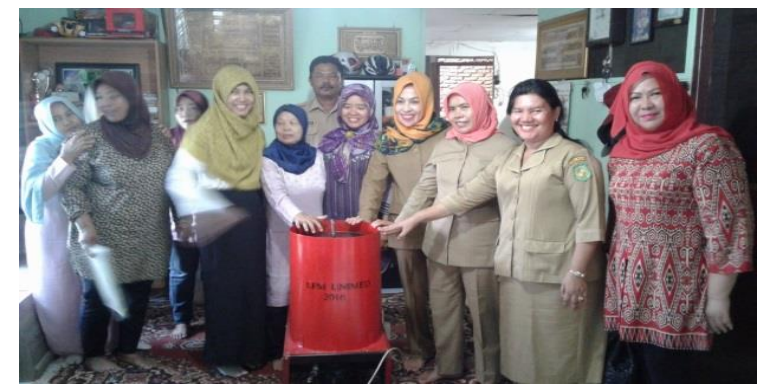

Gambar.1 Penyerahan Alat Produksi (Mesin Pengering Minyak) Oleh Ketua Tim Pengabdian kepada Ketua Kelompok UPPKS Lestari disaksikan oleh Kepala Kelurahan Sei Sikambing, perwakilan BKKBN dan Perwakilan LPM Unimed.

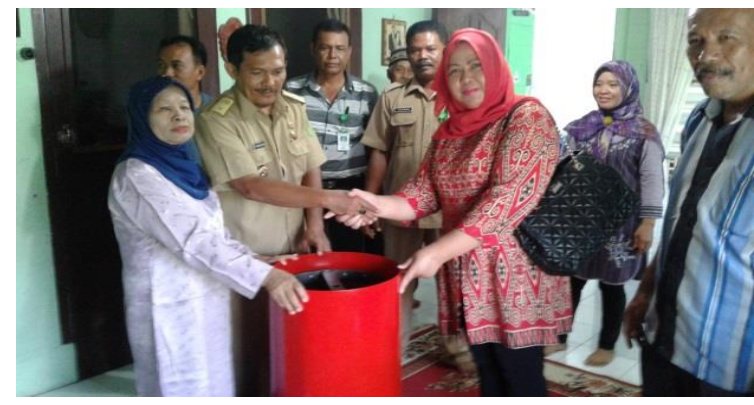

Gambar.1 Penyerahan Alat Produksi (Mesin Pengering Minyak) Oleh Ketua Tim Pengabdian kepada Ketua Kelompok UPPKS Lestari disaksikan oleh Kepala Kelurahan Sei Sikambing, perwakilan BKKBN dan Perwakilan LPM Unimed. 


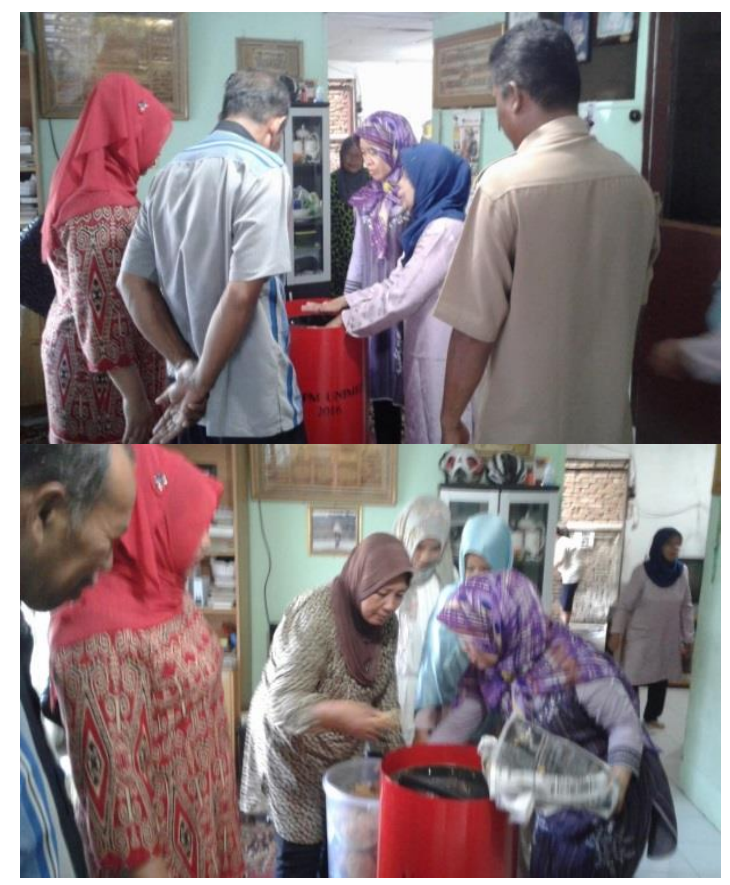

Gambar.2 Praktik Penggunaan Alat Pengering Minyak

\section{b. Aspek Manajemen Usaha Sebelum kegiatan}

1. Jika sebelumnya mitra belum melakukan pencatatan atas setiap transaksi yang dilakukannya, sehingga perkembangan usaha belum dapat dipantau perkembangannya.

2. Kemasan produk menggunakan plastik putih.

3. Pemasaran masih sebatas memenuhi orderan atau pesanan.

\section{Setelah Kegiatan}

1. Mitra sudah mulai melakukan pencatatan atas setiap transaksi yang dilakukannya, hal ini nantinya akan memudahkan mitra untuk memantau perkembangan usahanya dan juga dapat digunakan sebagai referensi untuk memperoleh kredit permodalan dari perbankan.

2. Kemasan produk menggunakan plastik putih dan diberi label/stiker yang desainnya disesuaikan dengan keinginan mitra dan di cantumkan merek dagang mitra, kode produksi, label halal dan B POM MUI, hal ini sangat membantu dalam hal perbaikan kualitas pemasaran produk mitra, saat ini produk mitra sudah dapat dititip jual di toko roti mawar yang memiliki lebih dari 30 cabang di kota medan dan sekitarnya dan kedepan sedang dilakukan penjajakan ke toko-toko roti ang lain seperti mjestik dan lain lain.
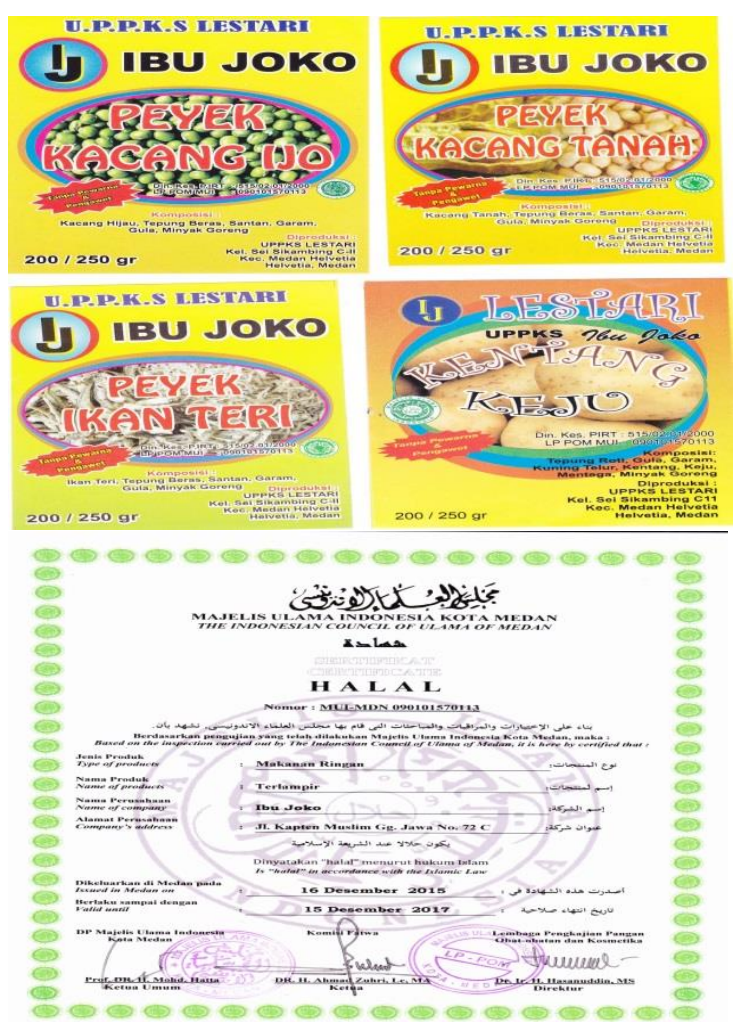

Gambar 3. Stiker kemasan dan sertifikat halal dari MUI

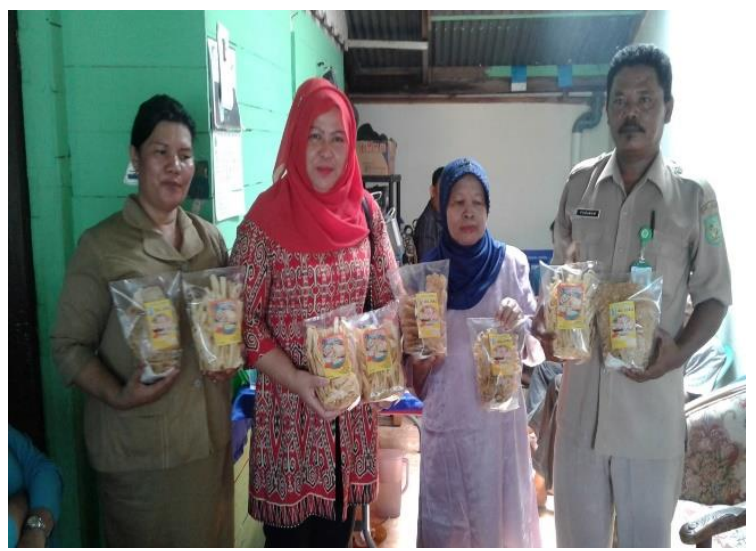

Gambar. 4 Produk mitra dengan kemasan dan siap untuk dipasarkan

\section{KESIMPULAN DAN SARAN \\ Kesimpulan}

Dari hasil pendataan keluarga yang dilakukan oleh BkkbN, diketahui bahwa $56 \%$ dari 39,4 juta keluarga Indonesia masih berada dalam tahap tertinggal yang termasuk dalam kategori keluarga pra sejahtera dan keluarga sejahtera 1. Dari jumlah tersebut 11,5 juta keluarga tinggal di desa tidak tertinggal. Data ini menunjukkan bahwa sebahagian masyarakat kita masih hidup dalam kemiskinan dan belum dapat ikut serta menikamati hasil-hasil pembangunan.

Kelompok UPPKS Lestari terbentuk sejak tahun 2012, merupakan salah satu wadah khususnya ibu ibu rumah tangga di kelurahan sei sikambing C 
dalam upayanya meningkatkan kesejahteraan keluarganya dengan memproduksi rempeyek (kacang tanah, kacang ijo, dan udang kecepe), stik keju dan jenis keripik lainnya.

Dalam berproduksi mereka sudah mandiri, namun kualitas produk masih perlu diperbaiki, mitra telah diberi alat yang mereka butuhkan berupa alat pengering minyak yang dapat membantu perbaikan kualitas produknya dan mitra juga berkeinginan memiliki alat pemecah kacang tanah agar lebih efisien dalam melakukan pekerjaannya.

Untuk memantau perkembangan usahanya, mitra sudah melakukan pencatatan atas setiap transaksi yang dilakukanya.

Untuk perbaikan kualitas pemasaran, kemasan produk mitra sudah diperbaiki dengan menambahkan stiker yang mencantumkan izin usaha, merek dagang, kode produksi, label Halal dan B Pom, sehingga produk mitra layak dipasarkan ke took roti maupun swalayan yang ada di kota Medan dan sekitarnya.

\section{Saran}

1. Hendaknaya kelompok UPPKS lebih mandiri dalam menjalankan usahanya

2. Hendaknya pemerintah dan pihak terkait, terus merancang program program pemberdayaan dan pengembangan UMKM yang tepat sasaran yang berkelanjutan dan bermanfaat bagi pelaku UMKM seperti kelompok UPPKS Lestari di desa Sei Sikambing C Kota Medan. 